\title{
Correction to: An Energy-Aware Trust and Opportunity Based Routing Algorithm in Wireless Sensor Networks Using Multipath Routes Technique
}

\author{
Maryam Hajiee $^{1} \cdot$ Mehdi Fartash $^{1} \cdot$ Nafiseh Osati Eraghi ${ }^{1}$ \\ Published online: 16 October 2021 \\ (c) Springer Science+Business Media, LLC, part of Springer Nature 2021
}

\section{Correction to: Neural Processing Letters (2021) 53:2829-2852 https://doi.org/10.1007/s11063-021-10525-7}

In the original publication, the third author's name was published incorrectly. The correct name should read as 'Nafiseh Osati Eraghi'.

Publisher's Note Springer Nature remains neutral with regard to jurisdictional claims in published maps and institutional affiliations.

The original article can be found online at https://doi.org/10.1007/s11063-021-10525-7.

$\bowtie \quad$ Mehdi Fartash

m-fartash@iau-arak.ac.ir

Maryam Hajiee

mhajiee2016@gmail.com

Nafiseh Osati Eraghi

n-osati@iau-arak.ac.ir

1 Department of Computer Engineering, Arak Branch, Islamic Azad University, Arak, Iran 